\title{
'n Lofrede vir taal
}

\author{
CS (FANIE) DE BEER
}

Emeritus professor

Universiteit van Suid-Afrika

Pretoria

Suid-Afrika

E-pos: Careldebeer17@gmail.com

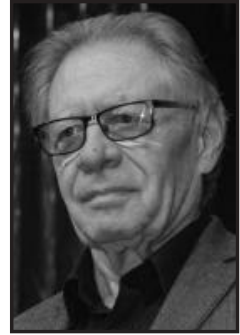

Fanie de Beer
C S (FANIE) DE BeER is Emeritus Professor van die Departement Inligtingkunde, Universiteit van Suid-Afrika.

Hy het gegradueer in Landbou en Filosofie (doktorale werk) aan die Universiteit van Pretoria en verwerf ' $n$ DEA, Universiteit van Parys X: Nanterre, Frankryk.

Hy het Filosofie, Kommunikasiekunde en Inligtingkunde aan verskillende universiteite doseer, het navorsing in al hierdie velde onderneem, daaroor gepubliseer en konsultasiewerk gedoen oor kennisskepping, -benutting, en -disseminasie.

Hy doen tans navorsing oor die volgende temas: die filosofie en teorie van inligting met besondere klem op teorieë rakende informatisering en plastisiteit, filosofieë en teorieë van tegniek en tegnologie; die etiek van kennis en wetenskap; lees- en interpretasieteorieë en die bestaande geletterdheidsnood; en oor die her-invensie van menslike spiritualiteit, noölogie en die gees van ons tyd.

Oor al hierdie temas het hy wyd gepubliseer.
C S (FANie) de BeER is Professor Emeritus of the Department of Information Science, University of South Africa.

He graduated in Agriculture and Philosophy (doctoral work) at the University of Pretoria, and acquired a DEA from the University of Paris X: Nanterre, France.

He taught Philosophy, Communications, and Information Science at various universities, undertook research in all these fields and was involved in consultation work in the area of knowledge creation, utilisation and dissemination.

He is currently engaged in research on the following themes: the philosophy and theory of Information with special emphasis on theories of informatisation and plasticity; philosophies and theories of technics and technology; the ethics of knowledge and science; reading and interpretation theories and the existing literacy needs; and on the re-invention of human spirituality, noology and the spirit of our age.

He has published widely on all these themes. 
"You don't just go and do anything with language; it preexists us and it survives us ... a language is not something that belongs. " Jacques Derrida

"The speaker moves into the infinitude of language ... and asks us to believe with him that language is not to be reduced to communication." Roland Barthes

"Language was by no means primarily the gift of speech ... but, on the contrary, the world essence ... from which speech arises. " Walter Benjamin

Die rede vir hierdie essay lê in my belewenis van en lewe in 'n taal wat vir my veel meer beteken as wat die afgelope jaar of meer se geraas aangaande my taal in my land aan gepraat en geskryf oor die plek en betekenis daarvan opgelewer het. Dit het my veel meer laat dink aan die gebrabbel waarvan Steiner (2001) melding maak as aan werklike intellektuele en verantwoordelike gesprekke, met enkele uitsonderinge hier en daar. Een rubriekskrywer het heel tereg verwys na "die stotterende debat" oor taal. Die minseggende aard van hierdie artikel het self miskien uit die aard daarvan van die skrywer 'n medestotteraar gemaak. Die debatte het veral gehandel oor die uitfasering en selfs verwerping van Afrikaans as onderrigtaal aan onderwysinstellings en by implikasie die bedreiging, al dan nie, van die voortbestaan daarvan.

Dit is wel goed dat baie mense gretig en redelik intelligent hieroor skrywe. Tog is daar heelwat herhaling en uiteindelik blyk een algemene tema dieselfde te wees ongeag of ' $n$ persoon ten gunste daarvan is of daarteen gekant is. Deur die bank word taal verstaan as 'n instrument vir kommunikasie en niks anders of meer nie, selfs in die pleidooie vir die behoud daarvan. In die proses is allerlei argumente gebruik om die verwerping van Afrikaans as onderrigtaal te regverdig, dikwels met allerlei onwaarhede, ideologiese standpunte en misleidende en bedrieglike argumente versier. Vandaar die lys van drogredes wat gebruik word as motivering om Afrikaans uit te faseer. Hulle bevat wel soms 'n skyn of sweempie van waarheid, maar dit is nie absoluut nie, hoewel dit volgens baie in die regte posisies, meer as voldoende argumente is en as absoluut voorgehou word.

Hierdie drogredes is nie toevallig nie, en ook nie eers sorgvuldig uitgedink nie, want dit speel af in ' $n$ bepaalde goedgevormde en sterk geïnspireerde ideologiese konteks van 'n bepaalde kennis- en wetenskapopvatting. Die agtergrond hiervan is die empirisme, rasionalisme, positivisme en later ook ekonomisme, opvattinge met 'n internasionale impak. Die kern hiervan is die tasbare, meetbare, feitlike en dus berekenbare terwyl niks anders as waar of werklik te beskou is nie. So word almal binne universiteite en selfs ook skole grootgemaak en gedwing om hiervolgens te dink. Ons het te doen met 'n soort verslaafde denke, beperkende denke, gevange denke, eerder as bevryde of bevrydende denke, 'n soort blinde intelligensie (domheid) - erg reduksionisties.

Hierdie manier van dink gee ook die toon aan vir ons opvattinge en uitsprake oor taal, soos oor byna alle ander sake. Twee woorde van Michel Serres is sprekend van hierdie tendens en in hul betekenis hoogs relevant vir wat met taal gebeur, naamlik thanatokrasie (die mag van die dood) en pragmatogonie (die skeppende krag van die dinge, teenoor die kontrolerende mag van subjekte oor dinge wat as deel van die thanatokratiese afgewys moet word). Hierdie terme is beskrywend van ' $\mathrm{n}$ soort geestesklimaat en geesteshouding waarvolgens dit maklik is om met taal af te reken. Wat dood is en hanteerbaar is, kan met die grootste gemak verruil en uitgeskakel word. So gebeur dit met baie dinge in die werklikheid en nie slegs met taal nie.

Die ander kant van hierdie reduksionistiese opvatting van kennis, waarheid en werklikheid, wat ook taal raak, word eenvoudig geïgnoreer of bespotlik en selfs soms met 'n tikkie snedigheid voorgestel: wie hierdie ander kant beklemtoon, is breindood. Volgens Michel Serres (1995:126) het kennis egter twee modi: die besorgdheid oor verifikasie en die eise wat dit stel, maar ook 
die neem van risiko's, die produksie van nuutheid, die veelvoudigheid van gevonde objekte, kortweg inventiwiteit. Ons mag nie die een bo die ander verkies nie; begin by een en gaan dan voort na die ander. Dit geld ook ons kennis van en denke oor taal. Serres (1995:147-148) voeg ook iets baie insiggewend op 'n ander plek by oor hierdie twee tipes kennis: Hy verwys na die Romeinse en Egiptiese kulture wat begrawe, verberg, wegsteek en iets in die skadu plaas teenoor die Griekse kultuur wat alles in die lig wil bring as kenmerkend van twee tipes kennis. Dit is vergelykbaar met sy vorige punt en hy beklemtoon dan hoe ons gekondisioneer is om altyd die tweede tipe te kies, hoog te ag en te beoefen. Om iets uit die skadu te haal, kan dit vernietig; om dit in die skadu te plaas, kan dikwels beteken om dit te behou. En dan beklemtoon hy: "We should invent a theory of obscure, confused, dark, non-evident knowledge - a theory of 'adelos' knowledge (something that is hidden and does not reveal itself) ... Shadow accompanies light just as antimatter accompanies matter." Kristal en rook is beelde wat 'n ander wetenskaplike (Henri Atlan 1986) gebruik om dieselfde gedagte te beklemtoon en te beskrywe, naamlik dat die werklikheid veel meer omvat as die meetbare en die tasbare.

Ons moet daarvan wegkom om alles te reduseer tot iets minder as wat dit is. Alle objektivering is reduksionisties, dus dodend (thanatokraties). Alle objekte bestaan in 'n konteks wat medebepalend is vir die betekenis daarvan. En dit is presies hoe ons ook oor taal moet dink. Bruno Latour (1988:153-157) skrywe oor sy “irreduksionistiese" versugting die volgende: "What happens when nothing is reduced to anything else? ... What happens when we give up this burden, this passion, this indignation, this obsession, this flame, this fury, this dazzling aim, this excess, this insane desire to reduce everything? ... Would the sky fall on our heads?" Ons behoort ook nie taal te reduseer tot blote gereedskap nie.

Teen hierdie agtergrond moet die verwysing na drogredes verstaan word en die miskenning van hierdie komplekse siening van kennis, en ook van taal, maak dit onmoontlik om anders oor sake te dink as in terme van drogredes. Dít kan nie anders nie as om te mislei en te bedrieg en te reduseer, al is dit ook onder watter lofwaardige voorwendsels en voortreflike argumente. Die verwonding en miskenning van die waarheid is tekenend van die taaldebat soos ook van die debatte oor baie ander sake.

\section{HEERSENDE DROGREDES OOR TAAL}

Taal as sondebok: Nie die Afrikaanse taal nie, maar sekere gebruikers daarvan kan moontlik sondebokke wees. Anders was veral Engels, maar ook Duits en Frans, Russies, Spaans en Portugees inderdaad veel groter sondebokke. Baie het in Afrikaans apartheid beveg. Taal behoort dus niemand se vyand te wees nie. Ellul (1985:177) skrywe: "The notion that language is the enemy only conveys the absolute poverty and helplessness of its zealous advocates".

Taal as professionele struikelblok: Dit sou jongmense steur in die vind van 'n beroep en bied geen waarborg vir loopbane en sakesukses nie. Daar bestaan baie goeie voorbeelde wat die teendeel bewys.

Taal as duur ekonomiese entiteit: Dit kos te veel om in meer as een taal onderrig te gee. 'n Lagwekkende argument veral komende van politici en hul meelopers vir wie daar geen beperking op die mors van geld is nie. Slegs Engels is glo hier in tel want dit vorm die basis en is die kommunikasiemedium. "In die industrie en sakewêreld is die woordeskat Engels" is die standaardsin wat gebruik word. Engels is glo die taal van die ekonomie. Niemand het nog van vertaling en die gefassineerdheid daarvan en daarmee gehoor nie. Is Engels miskien die voorwaarde vir die ekonomiese suksesse van die Skandinawiese lande - die rykste lande in die wêreld? 
Taal en gebrekkige studiemateriaal: Handboeke is boonop alles in Engels. Die ryk avontuur van vertaling, of die skepping van handboeke en ander studiemateriaal in Afrikaans, is klaarblyklik vir akademici sowel as vir studente te veel gevra.

Taal as struikelblok vir die internasionale status van universiteite: Intussen word maklik vergeet dat universiteite in die algemeen vervlak het tot middelmatige taalgebruik en lae vlakke van geletterdheid. Die vraag kan wel gevra word: Het of bied slegs Engelse universiteite internasionale status? Bowendien is dit oor 'n lang tyd die ervaring van baie studente afkomstig van Afrikaanse universiteite dat toegang tot Amerikaanse, Engelse, Nederlandse en selfs Franse universiteite redelik vanselfsprekend was.

Taal as uitsluitingsmeganisme: Alle tale sluit uit, ook Engels vir diegene wat dit nie magtig is nie. Hierdie uitsluiting spreek vanself en het niks te doen met diskriminasie teen mense nie behalwe in die logika van sosiale manipuleerders.

Taal as sosiale kohesie-meganisme: Die toppunt van skaamtelose en anargistiese sosiale manipulering. Hier word Engels opgedis en verheerlik as die magiese mag wat mense versoen! Om mekaar te verstaan tot op 'n sekere betreklik elementêre vlak is nog geen waarborg vir kohesie nie. Baie taalgelyke bure leef nie noodwendig in kohesie nie en deesdae al hoe minder. Met sekere gedragsuitinge in die gedagte verkies baie mense deesdae juis om nie samehorig te wees nie. Same-lewing, sosiale kohesie, het boonop ander voorwaardes as bloot 'n tweederangse gemeenskaplike taal as instrument nodig. Dit vereis volwasse individue waarsonder geen kohesie volvoer kan word nie. Die probleem wat in die weg staan, is eerder 'n soort infantilisme.

Taal as steurnis vir die droom van demokrasie: Die waarde van alle waardes is die stem van die meerderheid. Die meeste studente verkies Engels. Is dit inklusiwiteit om die betekenisvolle minderheid wat onderrig in Afrikaans verkies te dwing tot eentaligheid? Taalregte is nie meerderheidsregte nie, maar individuele regte. Wanneer $15 \%$ uit 40000 studente verkies om in Afrikaans te studeer dan raak dit 6000 individuele studente. Hulle word hul regte ontsê. Hulle word met mag gedwing om te kapituleer. Hulle het immers ook aanspraak op volwaardige institusionele akkommodering. Hulle mense betaal belasting vir al die ander, maar nie vir hulleself nie! Hoe werk so 'n demokrasie? Indien drie universiteite elk 6000 studente het wat verkies om in Afrikaans te studeer beteken dit 'n totaal van 18 000. 'n Volwaardige universiteit of nie? Mandela was byvoorbeeld uitgesproke daaroor dat die taalregte van Afrikaners en sekerlik van alle Afrikaanssprekendes nie geskend mag word nie.

In 'n ware demokrasie moet die regte van almal en nie slegs dié van die meerderheidsparty nie respekteer word. Die meerderheidsparty mag selfs 'n minderheidsparty word en die nuwe meerderheid mag anders dink. Verantwoordelike politici behoort hiermee rekening te hou en so ook universiteitsowerhede.

\section{Nadat die slag uiteindelik op grond van die drogredes gelewer is, word nuwe vertroostende drogredes opgestapel:}

"Taal en veeltaligheid": Om net een taal te hê, is die waarborg vir veeltaligheid. Dit klink soos idiote wat idiote regeer - rektore en universiteitsrade wat kwalik kan somme maak. Reduseer alles tot een dan het ons vele.

"Ons sal nie Afrikaans afskeep nie": Hierdie is berugte woorde van verskeie welsprekende Afrikaanssprekende vegters vir Engels. Sou dit beteken om binne universiteite nog Afrikaans 
te besig, of, sou dit beteken om Afrikaanse artikeltjies in Afrikaanse koerante te publiseer, soos sommige doen, as teken dat Afrikaans nie afgeskeep gaan word nie?

"Afrikaans sal steeds sy plek behou": Die wysheid van sekere wyses. Maar watter plek? Op die kantlyn, volgens die siniese kommentaar van een rektor, of as seremoniële taal, wat dit ook al mag beteken, volgens 'n ander rektor? Of waar anders?

"Afrikaans moet net reg bestuur word": Nog 'n brokkie wysheid van 'n veel geroemde kenner. Maar weer: Wie sal die bestuurwerk doen, en waar sal dit gebeur?

"Afrikaans moet saam met die ander tale uitgebou word": Hoe en deur wie en tot wat en wanneer? Asof die taal nie reeds uitgebou is nie tot 'n volwaardige akademiese en intellektuele taal wat nou van hierdie enorme prestasie beroof word. Let op die opmerkings in die volgende paragraaf.

Verspotte vertroostinge vir dommerds.

Opsommend: Al die drogredes is op dieselfde lees geskoei: Taal word bloot as gereedskap en slegs as gereedskap verstaan.

Let op die motto's!

\section{WAT WORD VERWERP?}

Let op wat werklik verwerp word en van die tafel gevee word wanneer van Afrikaans ontslae geraak word. 'n Volwaardige akademiese taal wat veral "taal se hoër funksies" bevredig. 'n Taal wat 'n WAT, HAT, AWS het en verskeie uitstekende vakkundige woordeboeke, wetenskaplike en akademiese boeke oor talle dissiplines heen, ontwikkelde studiemateriaal in Afrikaans in alle dissiplines, verhandelings en proefskrifte op alle vakgebiede, fiksie en digbundels van formaat. Unisa se reuse-rol in hierdie verband wat nêrens werklik erken word nie, verdien besondere erkenning - 'n institusie wat ook nou eentalig word om veeltalig te wees. Die feit dat dit alles net eenvoudig van die tafel gevee word, laat 'n mens sprakeloos. Ons moet egter nie vergeet nie: Ook hierdie prestasies, ongeag hoe spesiaal en kosbaar, is steeds deel van taal as gereedskap, buitengewoon kosbaar en die verwerping daarvan grens beslis aan die kriminele, so ook die lakse sorgeloosheid om dit verder te ontwikkel. Opmerking: die versnippering van "nuttelose" boeke kom eintlik maar neer op die verbranding van boeke. Die verbranding van boeke kan maklik lei tot die verbranding van mense merk Steiner (2001) op. Ons moenie verbaas wees as die verbranding van lesinglokale en laboratoria die afgelope tyd dieselfde gevolge kan hê nie. Daar is wel diegene wat inderdaad die versugting uitspreek dat Afrikaners liewer selfmoord moet pleeg.

Ek wil egter nie konsentreer op dit wat verwerp word nie, hoewel dit 'n volwaardige lofrede regverdig en verdien, en ook nie op die drogredes nie. Taal is veel meer as gereedskap en dit is die fokus van hierdie essay.

\section{NOODSAAKLIKE BESINNING OOR TAAL}

Die drogredes spruit nie alleen voort uit 'n verskraalde kennis- en wetenskapopvatting nie, maar die drogredes oor taal spruit waarskynlik voort uit en word versterk deur die "mishandelinge en aftakeling en verwoesting" van taal wêreldwyd. Dit is geen nuwe verskynsel nie. Die Sprachkritik in Duitsland is een voorbeeld. Beide Stiegler (2013:72), en voor hom Steiner (2001:234), het aangetoon hoe taal byvoorbeeld verval het en mishandel is in die Nazityd. 
Ons het wel in die uitskakeling van Afrikaans aan universiteite heelwat politieke korrektheid, sake-korrektheid en professionele korrektheid in die drogredes raakgeloop, maar ongelukkig min pedagogiese korrektheid en geen wesenskorrektheid nie, want die vermoë tot behoorlike denke het verlore gegaan. Dit is waar ons, ter wille van taal en ons eie geestesgesondheid, tog moet probeer uitkom. Om dit te vermag, is die bedoeling met hierdie gesprek geensins om behoorlik in te gaan op die drogredes en dit te probeer beantwoord nie. Die bedoeling is veel eerder om uit te kom by dit wat in die prosesse van sosiale manipulering ten opsigte van taal van die tafel gevee word, afgetakel en geruïneer word, eenkant geskuif word en tot niet gemaak word. Met ander woorde, om aan te dui wat wesenlik en nie bloot gereedskapmatig is nie en in hierdie misdadige prosesse eintlik skade ly. Vandaar die lofrede vir taal, opgedra aan taal soos dit in wese hoort te wees - die werklike synswyse van taal moet verheerlik word en nie tot niet verklaar word deur ongeletterdes of skyngeletterdes nie! Dit is ' $n$ lofrede vir taal as sodanig en dus ook vir Afrikaans as volwaardige taal, waar volwaardigheid veel meer en anders is as wat bedoel word met die sogenaamde hoër funksies van taal. In hierdie opsig is ook Venda, Zoeloe, ensovoorts inderdaad volwaardige tale. In wat volg, sal ek probeer om hierdie standpunt, naamlik wat taal spesiaal en uitsonderlik maak, te belig.

My ervaring en belewenis van en lewe in my taal, en my nabyheid aan my taal, inspireer my tot die myns insiens noodsaaklike besinning oor taal en waaroor dit regtig en ten diepste in taal gaan aan die ander kant van en ver verby die drogredes se trefwydte, wat ook verklaar waarom so baie eenvoudig versot is op hulle taal en eerlik treur oor die verwoesting daarvan. Besinning verstaan ek dan in die sin wat Heidegger daaraan gee wanneer hy skrywe: Besinning is die moed om die waarheid van jou eie vooronderstellinge en die gebied van jou eie doelstellinge tot die belangrikste vrae te maak!

Die drogredes spruit uit hierdie versteekte voorkeure en aannames en mooi geartikuleerde doelwitte wat dikwels ver van die waarheid is omdat dit geïnspireer word deur ideologiese oortuigings soos politieke korrektheid, volgens sekeres, en finansiële en sake-oorwegings, volgens andere, of 'n geriefliker mengsel van die twee, wat nog gevaarliker is, dikwels gekamoefleer met kwasi-opvoedkundige motiveringe. Om nie te praat van die vooronderstellinge wat die interpretasie van die goedgedokumenteerde goëlery betreffende die opnames en peilings van studentevoorkeure gerig het nie.

Terwyl hierdie diep en ernstige nadenke en die pyn wat die genoemde geraas in die media in baie gemoedere meegebring het, my besig gehou het, het ek gedurende hierdie tyd heel onverwags op verstommende materiaal in die literatuur afgekom wat die dringende nodigheid van so 'n besinning beklemtoon en die ervaring van pyn op 'n manier verduidelik. Ek lees dat Martin Heidegger (1947; 1973) skrywe oor "die snel voortwoekerende verwoesting van taal", dat Jacques Ellul (1985) 'n boek skrywe oor die "vernedering van taal", dat Paul Ricoeur (1991) praat en skrywe oor "die instrumentalisering van taal" as die grootste bedreiging van ons kultuur, en dat Bernard Stiegler (2013) dit het oor "die marteling van taal" of "taal as martelaar" vanweë die tegniese en digitale manipulering van alles, ook van taal. Uit elk hiervan moet 'n mens aflei dat taal volgens hierdie denkers iets oneindig veel meer en heel besonders moet behels wat dan verwoes, verneder, ge-instrumentaliseer of gemartel kan word. Die woorde wat gebruik word, is uiters venynige woorde om te beskrywe wat met taal gebeur. Dit gebeur nie slegs met taal nie; dit gebeur ook met die werklikheid, met die wêreld, met die lewe, met die aarde, met menswees, met onderwys, met 'n sinvolle bestaan, ensovoorts.

Belangrik sou dan wees om by hierdie dieper idee van taal uit te kom voor dit verwoes is, begrip daarvoor te ontwikkel, ten einde te besef wat werklik verwerp word wanneer taal verwerp word, na te dink oor wat hierdie woorde ten diepste beteken en wat die implikasies 
daarvan is, en uiteindelik te verwyl by die kernvraag van wat ons te doen staan om die saak te beredder. Kom ons probeer.

Die ononderhandelbare voorwaarde hiervoor is die besef dat taal ander dimensies het, ver verby hierdie moontlikhede van gereedskap: taal doen dinge; taal handel! Hierdie besef word gevoed deur 'n ander soort werklikheidsbesef ver verwyderd van empirisme, positivisme, ekonomisme, daardie werklikheid wat tevore beklemtoon is. Hierdie besef bring 'n ander besef van taal na vore; dit genereer lofredes vir en oor taal! Voorbeelde van wat gebeur is volop: Etienne van Heerden merk in 'n TV-onderhoud oor sy jongste boek op: my boek skryf my. Heidegger (1947) en Lecercle (1990) beklemtoon in hierdie verband: Ek praat taal, maar ... taal praat ook my, en deur my. Nou is taal nie meer my gereedskap nie, maar ek word gereedskap daarvan. Dit is die restant van taal! Ook Bachelard (1969) maak die belangrike opmerking rakende sy doseerwerk: "Soms dink ons woorde vir ons".

Julia Kristeva onderskei tussen die abstrakte en materiële dimensies van taal. "Abstract language is systematic, it transcends the individual speaker, separated from any physical or material origin, it is an instrument of control, mastered by a regulating subject. Material language is unsystematic, a series of noises, private to individual speakers, not meant to promote communication, and therefore self-contradictory ... It is an integral part of the speaker's body, an outward expression of its drives. It imposes itself on the individual, controlling the subject: it is not the transparent medium which the instrumentalist describes ... Neither of the two languages exists on its own, as an independent entity: material language is repressed and returns to the surface as a disruptive force, and the dictionary is an abstraction which denies the material expression of instincts" (Lecercle 1985:44-45).

Michel Serres (2015:90-92) bevestig soos volg dieselfde gedagtes in 'n betreklik onlangse radiopraatjie oor poësie: "Ons bedien onsself van taal om te kommunikeer, om die nuus aan te kondig, om mekaar te groet. En dit oortuig ons dat taal slegs daar is vir kommunikasie. Wel, geheel en al nie. Ek glo dat taal presies antwoord op die vraag wat gestel word deur die onderskeid tussen praxis (praktyk) en poiesis (werk). Wat fabriseer ons deur taal? Die antwoord is eenvoudig: ons fabriseer onsself deur taal. Taal gee vir ons die besef wat ons het van onsself, wat ons het van ons eie liggaam. Ons kan nie bestaan sonder taal nie. Dit fabriseer (maak) ons. ... Taal is belangriker as blote kommunikasiemiddel, die uitruil van gedagtes, want dit is waardeur ons onsself maak (fabriseer) en wat ons onderskei van diere. Taal maak van ons die individue wat ons is, mense. Poësie doen 'n beroep op hierdie aktiwiteit van taal. Hierdie aktiwiteit wat onsself fabriseer. Dit maak ons liggaam, ons gees, ons bewussyn, ons menswees, ons aard (wese). Hierdie poësie is absoluut onmisbaar, want dit skep sigself en beland so op die vlak van musiek wanneer musiek die meeste moontlike sin het omdat dit geen sin meer het nie. Soos musiek, so is poësie ook 'n aangeleentheid van ritme...'. Steiner (2005:76-78) beaam hierdie gedagtes: "The more fierce the pressure of thought the more resistant the language in which it is encased. Language, as it were, is inimical to the monochrome ideal of truth. It is saturated with ambiguity, with polyphonic simultaneities. It delights in fantastication, in constructs of hope and futurity for which there is no proof. ... Thought limited to logical propositions, best expressed non-verbally, or demonstrably factualities, would be madness. Human creativity, the life-giving capacity to negate the dictates of the organic to say 'no' even to death, depend integrally on thinking, on imagining counterfactually. We invent alternative modes of being, other worlds - utopian or hellish. We re-invent the past and 'dream forward'. ... Language constantly seeks to enforce dominion over thought. In the stream of thought it generates whirlpools, which we call 'mental disorders' and those log-jams known as obsessions. Yet the interference, the 'muddying of waters' are also those of creativity." Hierdie gedagtes 
is al heelwat vroeër deur Benjamin (1982:69-70) beklemtoon: "But do we not generally regard as essential substance of a literary work what it contains in addition to information ... the unfathomable, the mysterious, the "poetic". Dit is sekerlik ook waar van ander "taalwerke". Tensy hierdie dimensie van taal, soos Serres, Steiner en Benjamin dit artikuleer, omhels word, sal niks kreatiefs gebeur nie. Totale bankrotskap is die uiteinde. Moontlikhede van invensie gaan tot niet.

Hierdie dimensie van taal kom in die gedrang wanneer taal verwerp en uitfaseer word. Hierdie dimensie kom ook in die gedrang met betrekking tot enige ander taal wat die taal vervang en as blote stuk gereedskap opgedwing word. Die diepgaande aard van hierdie verwerping moedig ' $n$ mens aan om hierdie verwerping as krimineel te bestempel. Die verwerping van hierdie rykbeskrewe dimensie van taal laat die ware liefhebbers van die taal in 'n staat van totale wanhoop en verarming. Dit geld vir die liefhebbers van die taal wat verwerp word sowel as vir die gebruikers van die plaasvervangende taal: dit verarm en dryf tot wanhoop. Geen wonder die volgende vier denkers beskrywe sodanige verwerping in baie sterk taal nie en die ongelukkig baie bondige bespreking van hulle standpunte bevestig hierdie stellinginname.

\section{ONTDEKKING IN DIE LITERATUUR}

\section{Martin Heidegger: Die verwoesting van taal}

In sy boekie Wat is dat-filosofie? $(1955 ; 1970)$ het Heidegger beklemtoon dat die heersende opvatting oor taal die wese daarvan in so 'n ernstige graad aantas, en dat hierdie opvatting so ingeburger geraak het, dat ons hierdie wese nie eintlik meer kan verstaan nie. "Wanneer taal uit sy element val, word taal 'n blote tegniek, word dit gesien as 'n instrument vir kommunikasie en niks meer nie". Dit kom daarop neer dat dit meer korrek is om te sê en te dink dat taal in diens van denke staan, terwyl denke eintlik in diens van taal is, veral as dit waar is dat denke antwoord gee op die aansprake van die Syn. Dit is moeilik om terug te kom by hierdie wese van taal, maar onteenseglik nodig dat deeglik daaroor besin moet word en gesprek gevoer moet word. In 1947 al, in sy Brief oor Humanisme (1973) beweer hy dat "de bezinning op het wezen van de taal een andere rang krijgen. Ze kan niet meer enkel taalfilosofie zijn" (Heidegger 1973:31). Hy verwys dan na Sein und Zeit, par. 34, waar hy dit het oor "wat die synswyse van taal as taal is". Dit gaan dus duidelik vir Heidegger oor die wese, die synswyse, van taal, dit wil sê hoe taal bestaan. En dan maak hy die punt: "De overal en snel voortwoekerende verwoesting van de taal tast niet alleen de esthetische en morele verantwoordelijkheid in alle taalgebruik aan. Ze komt voort uit een bedreiging van het wezen van de mens." En dan gaan hy voort: "Het in de laatste tijd veel en rijkelijk laat besproken taalverval" is nie die oorsaak nie maar die gevolg van die gebeurtenis "dat de taal onder de heerschappij van de moderne metafysica van de subjectiviteit byna onweerhoubaar uit haar element valt" (Heidegger 1973:32). Dit is sterk woorde wat Heidegger gebruik: verwoesting van taal, taalverval, uit haar element val, dus haar wese verloor. Hy verbind dit (hierdie aantasting van die wese van taal) aan die wese van die mens en die metafisika van subjektiwiteit en verder dat die verval en verwoesting die estetiese en morele verantwoordelikheid in alle taalgebruik aantas. Hy meen dus dat taalgebruik estetiese en morele verantwoordelikheid vra. Taal help om 'n etos (tuiste in die wêreld vir almal) te skep; vervalle en verworpe taal, maar veral ook taal as gereedskap, kan eenvoudig nie wêrelde skep nie en nog minder tuistes.

Nou is die vraag: Wat beteken die verwoesting, verval en uit element val? Antwoord: As gevolg hiervan weerhou die taal ons van haar wese en haar wese is dat "ze het huis van de 
waarheid van het Zijn is". Dit is wat taal is; ook Afrikaans - huis van die Syn, van die waarheid van die Syn. Dus: die verwoesting van die taal, of taalverval, neem ons weg van die Syn en die nabyheid van die Syn (die volle werklikheid) wat ook ons tuiste is of behoort te wees en boonop die moeite om te lewe nogtans die moeite werd maak. Ons raak dus tuisteloos. Boonop beroof dit denke daarvan om in diens van taal te wees, waardeur denkhandelinge eintlik taalhandelinge is. In hierdie rooftog word die mens ook van die eie wese beroof; dit is die gevaar wat die mens bedreig: ewige wesensverlies.

En dan: Die taal, in hierdie status van verval, stel sig veel eerder tot beskikking van blote wilsversoeke, ons bedrywighede as instrumente om oor die dinge (die syndes) werklike heerskappy te voer op rekenend-handelende, oorsaak-gevolg finaliseringe en wetenskaplikfilosofiese verklaringe en funderinge. Dit is alles ons woorde, maar gebeur en word benut binne die raamwerk van "taal as instrument". Hierdie is die milieu waarin ons met al ons debatte beweeg. Vanweë die verwoesting van taal kom ons in hierdie milieu tereg wat wel 'n milieu van die syndes is, maar terselfdertyd ook die milieu is van synsafwesigheid en synsnalatigheid.

Maar wel: Indien die mens tog ooit tot die nabyheid van die Syn wil deurdring, dan moet hy eers leer "om in die naamlose" te bestaan - loskom van die inhoud van die vorige paragraaf, dit wil sê die berekenende en die instrumentele. So iemand moet die verleiding deur die openbare mening en die onmag van die partikuliere bestaan erken. Mense moet voordat hulle praat hul eers deur die Syn laat aanspreek, op die gevaar af dat hulle onder hierdie aanspraak self weinig te sê sal hê. Slegs op hierdie manier word aan die woord die kosbaarheid van sy wese, en aan die mens die egte behuising, die woon in die waarheid van die Syn, teruggegee.

Die eenvoudige maar wesenlike feit is: "de mens slechts in zijn wezen weest, waarin hij door het Zijn word aangesproken. Slechts door deze aanspraakt heeft hy dan gevonden, waarin zijn wezen woont. Slechts uit dit wonen heeft hy taal als de behuizing, die het ekstatische voor zijn wezen bewaart. Het staan in de klaarte van het Zijn noem ik de ek-sistensie van de mens" (Heidegger 1973:36-37). Omdat die mens "vrij in de klaarte van het Zijn - en deze alleen is 'wereld' - zijn geplaats, ontbreek haar de taal niet'. Taal is nie die uiting van 'n organisme ook selfs nie uitdrukking van 'n lewende wese (plante en diere) nie. Taal is "lichtendverbergende aankomst van het Zijn zelf" (Heidegger 1973:39). Taal is dus veel groter as wat ons normaalweg dink. Taalverlies is synsverlies, bestaansverlies, eintlik lewensverlies tuisteloosheid, of, volgens Benjamin die verlies van "wêreld-essensie" (Kyk Arendt 1982:49).

Die advertensiewese misbruik hierdie effekte van taal vir eie gewin en gevolglik belewe ons hierdeur wat Heidegger (1973:32) beskrywe het as "de overal en snel voortwoekerende verwoesting van de taal" sodat die waarheid van die Syn en ons nabyheid aan die Syn verlore raak en so ook die moontlikheid van same-lewing en gemeenskap.

\section{Jacques Ellul: Die vernedering van taal}

In aansluiting by Heidegger se werk moet verwys word na Jacques Ellul (1985) se insiggewende studie oor "die vernedering van die spreke" wat eintlik ook neerkom op die vernedering, devaluasie, disintegrasie, haat en minagting van die woord en van taal (twee sake wat Ellul deurgaans aan mekaar verbind). Hy druk dit sterk uit: "We are all aware of the remarkable phenomenon that has left its mark on our era, the disintegration of language in various ways" (Ellul 1985:158). Die situasie van die woord in ons samelewing is afstootlik. "The habit of speaking without saying anything has eaten away at the word like a cancer" (Ellul 1985:155). En dan weer: "Mundane and intellectual chatter mixed together finally collapse into wordlessness" (Ellul 1985:156). De facto devaluasie! Hierdie devaluasie vind plaas deur 
slagspreuke, oorbeklemtoning van beelde, die tegnifisering van alles, en ook die objektivering van taal. Ons het in wese hier te doen met "die verdwyning van een soort denke ter wille van 'n ander soort denke" (Ellul 1985:159). Ons opvatting van taal weerspieël ons denkwyse. 'n Fatale denkverskuiwing vind plaas en dit sal in alles neerslag vind, nie net in taal nie. Die woord word gereduseer tot 'n blote instrument - 'n stuk gereedskap vir babbelaars. Dit is maklik om in hierdie lig van taal 'n objek te maak. Een vorm van devaluasie kom van rekenaars. Om die rekenaar ter wille te wees moet taal aangepas word: "Computers cannot understand ambiguities, connotations, allegories, metaphors, metonymies, ellipses, and paraphrases. Computers must have unambiguous language, with no double meanings, subtleties, or complexity. We also have to remain within a certain limited vocabulary. ... All the richness and openness of truth lie precisely in what must be eliminated in order for the computer to understand" (Ellul 1985:161).

Wat in die wetenskap met taal gebeur asook die soort houding wat oor taal gedemonstreer word, word soos volg deur Ellul (1985:167) verwoord: "Simple ideas are turned into something absolute by the scientific establishment, so as to crush that remainder of language that is not scientific [Kyk Lecercle (1990)] oor 'the remainder of language' (die restant van taal)]. By this very process ... such ideas become false, in the same now well-known way that pieces of reality do when science makes a fragment of reality its object and thus alters reality and loses its object!" Weer 'n keer word same-lewing wat steun op die "restant van taal" erg skade berokken, selfs onmoontlik gemaak. Hierdie reduktiewe misbruik van taal (Ellul 1985:167) bring dus ook die belangrikheid na vore om te besin oor die verhouding "individuering en wete" in die mate waartoe so 'n samevoeging 'n voorwaarde word vir die stigting van samelewing en gemeenskap.

Dan gee Ellul (1985:162vv) breedvoerig aandag aan die minagting van taal, maar om taal te minag en selfs te verag is egter nie die einde nie. Die haat vir taal is die volgende fase. Wat sig hier manifesteer, is eintlik 'n haat vir ons intellektuele erfenis en vir ons toewyding aan pogings tot tussenpersoonlike kommunikasie - 'n haat vir sin (“meaning"). Hierdie haat klink agterdogtig, meen Ellul. Dit vermy die harde vraag wat van taal self kom: taal stel die moontlikheid dat daar ' $n$ kraak in die muur is wat ons koorsagtig en doelbewus bou om onsself binne sinloosheid en subhumane delirium op te sluit. Maar daar is nog meer: Die haat van die woord word nog erger deur die identifikasie daarvan met 'n haat vir die mensheid. Snaaks genoeg word die haat eintlik uitgedruk as 'n verlange na vryheid, beweer Ellul.

Taal word gevorm met 'n woordeskat, sinsbou en vaste spelreëls. Dit is voorskrywend en volg norme en die sprekers, skrywers moet dit volg wat hulle nie geskep het nie. Onvryheid. Watter vryheid? Vryheid om my eie taal uit niks te skep. Sodra ek 'n taal leer, is ek dus van my vryheid ontneem. Dit is geweld teen my reg om myself te vestig, te bou as persoon. My identiteit is in die gedrang. Daarom haat ek die taal. Taal forseer my dus om my op 'n sekere manier te gedra. Ek was hiertoe gedwing toe ek myself nie kon verdedig nie of onskuldig was. Die instrument van hierdie mag was taal.

Een groot saak word in hierdie argument misgekyk: Taal is nie bloot wilde geluide nie; dit is die manier waardeur daar kontak met ander gemaak word. Taal as taal is iets wat gegee is en indien die gawe verwerp word, bestaan die taal gewoon nie. Niks nuut of vry word deur die verwerping geskep nie - geen vernuwing of bevryding nie. So 'n houding teen taal illustreer Pascal se punt: "he who would act the angel acts the brute" (Ellul 1985:174). Om van taal bevry te word, is om die moontlikheid van 'n verhouding met ander op te gee [nie om dit te skep soos by ons beweer word nie] en om dít op te gee wat die mensheid uniek maak: die woord. So 'n houding lei nie tot vryheid nie maar wel tot dwaasheid, meen Ellul. Taal het my gemaak wat ek is. Dit geld van alle gebruikers van die taal en nie alleen die misbruikers nie. 
Nog verder en ernstiger: die gebrek aan vryheid word nog verder beklemtoon wanneer die ideologiese fase bereik word. Dit is nie alleen 'n abstrakte kondisionering wat ek moes deurgaan toe ek jonk was nie; dit is 'n kondisionering wat my verplig om met 'n bepaalde ideologie te assosieer. "Language is an instrument of oppression and alienation used by the ruling class to keep the oppressed classes in bondage" (Ellul 1985:174). So word taal 'n subtiele instrument van verslawing. Hulle moet leer praat soos die meesters, diegene se idees aanvaar en dus gehoorsaam word. Ellul stel dit soos volg: "The ruling class makes the oppressed class learn its language in order to turn the oppressed into prisoners of the ruling class's ideology and to prevent them from thinking." Taal oriënteer diskoers en denke in 'n sekere rigting; dit is in hierdie sin 'n instrument van mag en beheer, meer te vrees selfs as polisie en sensuur, want dit word geïnternaliseer; dit beheer vanuit die onbewuste. Die gedagtes, denkbeelde, vooroordele, gesigspunte van die heersende klas moet oorgeneem word; taal word op hierdie wyse 'n tirannie oor denke; alles moet eenvoudig gereproduseer word; niemand kan ontsnap nie; almal word gevangenes van gesaghebbende singewings.

Die volgende element in die analise van taal is die woede teen hierdie taal wat gevange neem wanneer ek praat, wat my dwing om kant te kies vir die heersersklas. So 'n kwaai kulturele rewolusie is onmisbaar vir bevryding uit die heersersklas. MAAR: Hoe kan ons ontsnap aan alles wat taal self meedeel aangesien elke kontrarevolusie gevange bly in hierdie konformerende, steriele taal? So begin die anti-woord op 'n mees wyse manier, en alles word omhels wat heldergeestige, doelbewuste "vernietiging" van die uitruilwaarde van woorde produseer. Met sulke vanselfsprekende "feite" kan ons duidelik sien waarheen gedrywe is alles is die gevolg van para-Marxistiese ideologie en 'n oorvereenvoudigde analise van die verhouding tussen taal en kultuur. Die leegheid van hierdie intellektuele houding is vir Ellul eenvoudig om te verduidelik.

Sy eerste kritiek handel oor die opvatting van taal wat klop met hierdie houding: Hoe kan enigiemand nie raaksien nie dat die gewelddadige aanval op taal slegs geldig is indien daar ondersteuning is vir ' $n$ meganistiese en rigiede opvatting van taal en woord? Die opvatting: taal as instrument van oorheersing en verdrukking kan alleen 'n feit wees indien taal rigied en presies is. Dit sal slegs waar wees indien die woord ideologie presies reproduseer en daar geen leë ruimtes, kantlyne en spasies is nie.

Ons weet dit is nie die situasie nie, of, ons behoort te weet indien ons taal hoegenaamd verstaan. Inteendeel, diskoers is vol leë ruimtes; daar is frakture in woorde en gapings in taal. Die volmaakte reproduksie van die heersersklas is onmoontlik. Vreemde skeppinge en beelde word gereeld in die gapings in taal gebore. Onthou, baie sprekers van die taal (wit, swart, bruin) is ewe veel onderdruk. Boonop het menigtes in hierdie en deur hierdie taal geveg vir die bevryding van diegene wat nou die taal verniel en vernietig. Hulle is nie al wat onder die misbruik van die taal gely het nie! Afrikaanse fiksie, poësie, en essays is hiervoor gebruik. Dit is dus kortsigtig en krimineel wat hier gedoen word! En dit ondanks die krokodiltrane en moralistiese berou van sommige.

Sy tweede kritiek: Hoe kan taal beskuldig word van niks anders nie as die ideologie van die heersersklas, beelde van kapitalisme wat as waarhede verkondig word. Hoe kan dit ons gevange neem en verslaaf maak? Hoe kan enigiemand substansie verleen aan hierdie aansprake wanneer histories gesien, die woord, taal, voortdurend rewolusie fermenteer en ook die instrument is van groot rebelle in die wêreldgeskiedenis? Taal is dus nie strafbaar nie behalwe vir kortsigtige dommes. Watter middele het Robespierre, die Heilige Justinus, Marx, Lenin, Freire en baie ander gebruik. Taal was hulle krag en dit was nie Engels nie! 
Die oorheersende teen-heersersmentaliteit kom tot uitdrukking nie in beelde of handelinge nie, maar deur die "nuwe woord"! (Ellul 1985:176). Hierdie woord is samehangend en redelik en gee uitdrukking aan 'n analise, 'n idee, kennis, kritiek, aspirasie, en 'n utopie wat drasties radikaal verskil van al die woorde en leringe van die heersersklas. 'n Geldige vraag: Waar sal hierdie instinkte vandaan kom as alle ideologie die ideologie van die heersersklas reflekteer? Hoe kan taal uitdrukking aan die revolusie gee as dit slegs toegewy mag en kan wees aan konformiteit met die heersers.

In werklikheid is die woord in sigself revolusionêr. Slegs die woord en taal kan lei tot die verwesenliking van menslike hoop. Dit is vanweë die verhouding van taal tot waarheid. Die heersersklas veg om die woord te kastreer, om taal 'n eenvoudige neutrale instrument te maak, of selfs heeltemal uit te skakel.

Hoe kan niemand raaksien nie dat hierdie geveg teen georganiseerde taal, hierdie haat vir die woord, juis die verwesenliking beteken van die heersersklas se doelwitte. As taal vernietig is en niks meer sê nie is daar niks te vrees nie. Watter waansinnige dwaasheid om te dink dat deur die vernietiging van ' $n$ taal en die stroping van betekenis iets revolusionêrs bereik kan word.

Ongelukkig weerspieël die opvatting dat taal die vyand is die algehele armoede en hulpeloosheid van die vurige revolusionêres. Hulle kan niks teen hierdie gemeenskap vermag nie daarom wreek hulle hulle deur aanvalle op woorde wat hulself nie kan verdedig nie. "They misdirect their revolutionary energy against an imagined foe, achieving great victories against a weak construction. They pride themselves on their profundity, while the oppressor rejoices to see his adversary destroy what is potentially his own most faithful ally. Hatred of language and the word only manifests the impotence and vanity of conformist pseudorevolutionaries, the likes of which abound amongst intelligentsia" (Ellul 1985:177).

\section{Paul Ricoeur: Die instrumentalisering van taal}

Ricoeur se omvattende projek oor "tyd en narratief" (in drie volumes) was presies om die "inventiewe mag van taal" te ondersoek (Ricoeur 1991b: 463), maar nog veel meer: dit was die fokus van sy hele filosofieprojek. Hy skrywe: "My philosophical project is to show how human language is inventive despite the objective limits and codes which govern it, to reveal the diversity and potentiality of language which the erosion of everyday, conditioned by technocratic and political interests, never ceases to obscure" (Ricoeur 1991b:465). Hierdie inventiewe mag word alle Afrikaanssprekendes ontsê deur die verwerping van hulle taal. 'n Mens kan sekerlik hier ook die eroderende rol van die wetenskaplike in die algemeen, die bestuursmatige en ook die markverwante belange byvoeg as sodanige verduisteringe van die potensiaal van taal.

Aanvullend hiertoe is sy opvattinge oor "poësie en moontlikheid" ewe relevant (Ricoeur 1991a:449-462). Dit is die taak van poësie om woorde soveel te laat sê as wat dit moontlik kan sê en nie so min moontlik nie. Dit, naamlik om so min moontlik te sê, is presies wat gebeur in gewone taal, in onderrigtaal, in wetenskaptaal, in die taal van tegniek. Hierdie instrumentalisering van taal is vir Ricoeur die gevaarlikste tendens van ons tyd. Hy skrywe: "The first thing I should like to emphasize is that poetry preserves the width, the breadth of language, because the first danger in our present culture is a kind of reduction of language to communication at the lowest level or to manipulate things and people. So it's full of language which becomes merely instrumental. This instrumentalization of language is the most dangerous trend of our culture. We have only one model of language - the language of science [die 
meetbare] and technology [die digitale] [albei saam - die berekenbare] (Ricoeur 1991a:448). Hierby kan gevoeg word wat Ricoeur $(1976: 99,101)$ al heelwat vroeër gesê het: Alle vorme van instrumentele intelligensie is die medewerker van geweld en om nie-gewelddadig in diskoers te wees is om die meervoudigheid en diversiteit van tale te respekteer.

'n Groter bekommernis is dat 'n deel van die filosofie slegs hierop konsentreer, terwyl hy hierteenoor die verantwoordelikheid van die filosofie van taal soos volg skets: "to preserve the varieties of the uses of language and the polarities between these different kinds of language, ranging from science through political and practical language and ordinary language, let us say, and poetry. And ordinary language, mediating between poetry, on the one hand, and scientific language, on the other hand" (Ricoeur 1991a:448).

Hier moet ons onthou dat dit nie bloot gaan oor digting en digbundels nie. Ons lees in die voorwoord tot die prosa van Heidegger se Wat is dat - filosofie? die volgende stelling van die redaksie: "Hierdie fassinerende prosa besit sowel die strengheid van 'n teoretiese verhandeling as die seggingskrag van 'n digwerk", al is dit geen digbundel nie (Heidegger 1970:7). Kyk wat skrywe George Steiner (1978:26) oor Freud se opstel "Civilization and its discontents": "Freud's essay is itself a poetic construct". Let ook op wat Girard (2014:104) oor Levi-Strauss sê: "His great book on the elementary structures of kinship ... is unquestionably austere and rather technical, but what came after is as poetic as it is true. Levi-Strauss is one of the great poets of ethnology." Hy het egter sover my kennis strek nooit 'n digbundel geskrywe nie. Shosana Felman skrywe oor Jacques Lacan: “Lacan's writing read like Mallarme's - an obscure and enigmatic, yet powerful and effective, poetic prose" (Felman 1987:5). Geen wonder dat Hannah Arendt (1982:50) oor Walter Benjamin die volgende gevolgtrekking maak nie: "He understood language as an essentially poetic phenomenon".

Wat nou van die grootste bedreiging?

Ricoeur hoop op 'n "her-skepping van taal”. Hermeneutiek beklemtoon die verskillende funksies van of gebruike van taal, maar is veral ook besorg oor "die permanente gees van taal". Met "gees van taal" word bedoel "die kapasiteit van taal om nuwe wêrelde te open" (Ricoeur 1991c:489). Die vernietiging van Afrikaans is 'n simboliese gebaar wat sê: "Kom ons sny hulle, hierdie Afrikaanssprekendes af van die moontlikheid om nuwe wêrelde te open of te skep, en skep by hulle die onvermoë om die toekoms te sien". Die besef by diesulkes is afwesig: Taal as gereedskap kan nie wêrelde skep nie; en om die een stukkie gereedskap met 'n ander te vervang immobiliseer steeds almal en maak hulle dom. Geen wonder ons kom nie by werklike nuwe wêrelde uit nie. Die herskepping is veel meer en anders as die blote funksies van taal, selfs meer as die sogenaamde hoër funksies. Ter versterking van hierdie ander deel van taal sê Ricoeur: "In poetry language turns back on itself to celebrate itself" (Ricoeur 2013a:136). As taal sigself verheerlik, of vier, is dit geensins as 'n vorm van gereedskap te verstaan nie. Dit is 'n skeppende aktiwiteit. Dit klop met sy opmerking oor "die inventiewe krag van taal" (Ricoeur 1991b:463). Hierdie opmerkinge moet in gedagte gehou word wanneer dit lyk asof Ricoeur die poësie bloot sien as nog 'n funksie van taal. Vir hom is dit veel meer en anders. Wanneer hy skrywe oor die "permanente gees van taal", dat taal inventief is, en dat taal sigself vier, of, nuwe wêrelde open, is dit baie ver verwyder van taal as "gereedskap".

Dit is belangrik om die punt te maak: Die verlaging van taal tot gereedskap maak dit 'n uiters nuttige instrument vir manipulering, daarom is so ' $n$ taalopvatting tog so gepas in ons situasie van transformasie waar transformasie byvoorbeeld in so ' $n$ misvormde, verskraalde, eenduidige sin en wyse gebruik word dat almal dit kan verstaan - dit (transformasie) gaan slegs om sommetjies en nie oor dieper sake soos gesindhede nie. "Transformasie" soos dit hier te lande gebruik word, is 'n pragtige voorbeeld van die volledige verskraling en verarming 
van taal, die totale miskenning van die volle betekenis van die woord, selfs die vernedering en verwoesting daarvan. So 'n misbruik van taal dui ook op die marteling daarvan. Ons het baie sulke voorbeelde. Die universiteite loop oor daarvan.

\section{Bernard Stiegler: Die marteling van taal, of, taal as martelaar}

Taal konstitueer 'n proses van psigiese en kollektiewe individuering waarin 'n mens vind dat die voorwaarde van individuering is dat die taalmilieu neerkom op die deelname van almal aan die ontvouing van so ' $n$ taalmilieu. Taal is ' $n$ simboliese en ' $n$ intrinsiek deelnemende sosiale milieu waarbinne die proses van individuering gekonstitueer is tot die mate dat die aangesprokenes terselfdertyd ook potensieel aansprekers is. In wese is hierdie proses dus psigies en kollektief: sprekers individueer hulself, dit wil sê transformeer hulself en word wat hulle is deur die uitinge wat hulle produseer asook deur die uitinge wat hulle ontvang. Dit is die proses van dialoog of gesprek wat eie is aan taal. Hierdie uitinge self dra by tot die transformasie van die taal waarin dit uitdrukking vind, tot dieselfde mate as wat dit bydra tot die individuering van die spreker. Die psigiese individuering van die spreker kan hier net sowel die kollektiewe individuering wees wat die gewone taal vir sprekers konstitueer wat hulself konstitueer vir sover hulle praat. "The speaker is he who practices his language, not he who "uses" or "employs" it. One neither employs nor uses his language, he is constituted by it...." (Stiegler 2016:34).

Wat hier individuering genoem word en wat gekonstitueer word deur taal, die simboliese sisteem by uitstek, is belangrik omdat dis-individuering op verskeie gronde en wyses aan die orde van die dag is en dis-affektiewe individue en samelewings skep. Dit hou weer verband met de-simbolisering en albei hiervan kan direk met taal in verband gebring word. Industriële de-simbolisering het gelei tot die radikale herkonfigurering van die prosesse van transindividuering. Dit lei tot 'n degradering in die verhouding tot taal, tussen ons en in elkeen van ons, en in ons wyses van gedrag, handeling en denke, wat weer klem plaas op die degradering van ons geestestoestand, van ons moraal, van ons selfbesef en ons sosiale verhoudinge. Terwyl hiermee 'n ware agteruitgang in intellektuele vermoëns ontlok word, sal hierdie verlaksing van taal eindig met die skepping van 'n lakse taal, dit wil sê, gereed vir al die lakshede (Vergelyk byvoorbeeld die taal van die Derde Ryk in Duitsland) (Stiegler 2013:72). Vergelyk ook Steiner (2001:234) oor taal en die Derde Ryk.

Hierdie desimbolisering het rampspoedige gevolge vir veral jongmense met die implikasie van die verwerping van alle gesag: ouerlik, akademies, juridies, wetgewend, artistiek, en literêr. Hierdie devaluering is slegs ' $n$ element van die berekende houding van devaluering van alles en almal. Sodanige simboliese ramp, wat demoraliseer veral met betrekking tot die lewe van die gees, is as proses van desimbolisering planetêr in omvang. So sien ons dit selfs op groot skaal in Suid-Afrika.

Behalwe vir die industriële desimbolisering, maar ook as deel van hierdie proses, word hierdie omvattende aftakeling, of brutale degradering, van taal wat neerkom op 'n kortsluiting van kollektiewe individuering, veral deur tegnifisering, digitalisering en outomatisering van taal verwesenlik. Dit kom vir Stiegler neer op 'n misdaad teen die simboliese waarsonder die kind nie volwassenheid kan bereik nie, dus nie kan lewe en bestaan nie en dus as resultaat het dat dit eintlik 'n misdaad teen die jeug is. Hierdie vernietiging van taal, wat al die sosiale realiteite soos sorghebbende organisasies, terapeutiese modelle, werk, sosiale beskerming, opvoeding, reg, kultuur en wetes, selfs navorsing en wetenskap aan mekaar verbind en heg, 
word besonder treffend geïllustreer deur die disintegrasie van psigiese individuering tot op die punt van die ont-lering om te praat en te dink.

Teen hierdie agtergrond skrywe Stiegler (2013:84-88) dat taal die afgelope tyd so gely het dat dit nie oordrewe sal wees om van "die martelaarskap van taal" of "die mishandeling van taal" te praat nie, soos dit deur die nuwe proses van trans-individuering wat deur psigotegnologieë (tegnologieë van die kontrole van trans-individuering) opgedwing word. Die "martelaarskap van taal" het volgens Stiegler sekere gevolge. Die eerste gevolg: Die tegnologiese kontrolering van transindividuering is presies dit waardeur die sprekers beroof word van hulle vermoë tot spreke soos ook van hulle vermoë om te luister. Insiggewend is dat dit hier gaan om taal en nie oor ' $n$ spesifieke taal nie. Ons leef in 'n tyd van die vernedering, verwoesting, vulgarisering van taal met verwysing na Frans, Duits en net sowel na enige ander taal. In die hedendaagse opset het taal, ongeag watter taal, vir die gebruikers slegs 'n stuk gereedskap geword. Terselfdertyd kan taal, so afgewater, maklik as sondebok uitgekryt word sonder om te besef dat daar van die alternatiewe taal eweseer slegs 'n stukkie gereedskap gemaak is en niks meer nie. Die wese van taal as sodanig gaan dus verlore in hierdie proses. Die tweede gevolg: "Dit is waarom die praktyk van taal benaderd, lui (slordig) en in die finale sin diepgaande vulgêr geword het by elkeen van ons - niemand of byna niemand ontsnap aan die druk afkomstig, aan die een kant, van die effekte van dis-individuering en van desimbolisering, bewerkstellig deur die ge-dissosieerde milieus, wat sig gekombineer het". Die derde gevolg: "Aan die ander kant, afkomstig van die effekte van die advertensiewese en die aktiwiteit daarvan, wat beteken die besitname van taal deur die kultuur-industrieë [en polities gedrewe ideoloë].” Advertensiewese trek ook voordeel uit die poëtiese, retoriese, prosodiese (vertellende), pragmatiese, ensovoorts effekte wat die prosesse van transindividuering versterk, dit wil sê, in die deel van betekenisse, in die uitbuiting van die wetes wat van linguistiek en semiologie uitgaan. Die afgelope eeu het industriële advertensiewese op massiewe skaal ingemeng in hierdie prosesse van kollektiewe individuering wat taal is. Die advertensiewese kombineer met die linguistiese manipulering van die outomatiese hantering van natuurlike tale. Slegs berekeninge en algoritmes geld hier. Woorde word handelsware, danksy Google (Stiegler 2013:96-97). Taal as proses van kollektiewe individuering word verongeluk deur industriële advertensiewese, dus word taal gebruik as gereedskap, ... en die gevolg is: kollektiewe individuering, dit wil sê volwassewording, kan nie verwesenlik word nie. Infantilisme is ons voorland. Steiner (2001:223) praat van "manipulerende infantilisme". Die vierde gevolg: Die tegnologiese ontwikkelinge wat bydra, op die terrein van inligtingindustrieë, tot die ontwikkeling van industrieë van taal en van linguistieke tegnologieë, waarna verwys word as "die outomatiese behandeling van natuurlike taal" (Stiegler 2013:87-88) het tot gevolg die nadelige uitwerking van disindividuering, desimbolisering en van die beslaglegging op taal deur die advertensiewese.

Taal het in die martelaarskap op verskeie wyses slegs 'n stukkie gereedskap geword. Taal as gereedskap alleen kan nie same-lewing stig nie, want same-lewing is 'n synsaangeleentheid en hier verloor taal as gereedskap sy krag. "Die poëtiese, retoriese, prosodiese, pragmatiese, ensovoorts effekte van taal versterk juis die prosesse van transindividuering, dit wil sê, die deelname aan betekenisgewing as gesamentlike aktiwiteit en gemeenskapsbelewing (Stiegler 2013: 88).

Oplossings is moeilik te vind maar is nie onmoontlik nie en hier volg die parafrasering van 'n paar gedagtes van Stiegler.

Om degradering, desimbolisering en disaffektiwiteit, dus ook die aftakeling van taal, en die marteling daarvan, die hoof te bied vereis hersimbolisering. Dis ons taak en wat ' $n$ taak 
is dit nie. Wie is daarvoor opgewasse, of selfs: wie besef hoegenaamd dat dit die voorwaarde is? Die probleem is nie die taal nie; die taal is bloot ' $n$, of selfs die, simptoom van desimbolisering, disindividuering, met 'n diep impak op transindividuering, en 'n verlies aan lewensgevoel. Niks bly oor nie. Mense raak ontredderd, sondeboksoekend en vindend. Die vraag is hoe om hieruit op te staan?

Wêreldwye aandag is nodig. Daar moet begin word deur 'n einde te maak aan die vernietiging van taalkundige milieus en van die prosesse van psigies-infantiele individuering waarvan hulle die voorwaarde is. Die openbare welsyn van die wêreld hang hiervan af en onverskilligheid, stilswye, onbewustheid, en onverantwoordelikheid, veral deur openbare gesagsdraers en -figure is onaanvaarbaar, al sal hulle dit nie self insien nie vanweë hul eie verblinding deur eie ideologieë en allerlei slimmighede (drogredes).

Psigiese individuering moet verwesenlik word as die noodsaaklike voorwaarde. Dit kom veral, en voor alles, neer op simbolisering, dit wil sê om met ander hul individuering te deel, en dus ook kollektiewelik te individueer, duidelik met die oog op ander. 'n Normale verhouding tot taal is dus eerstens en in die primêre sin 'n verhouding van ko-individuering, dit wil sê individuering met ander as gespreksgenote met die verstandhouding dat 'n antwoord moontlik is en dat daar dus geluister word - 'n gesprek vind plaas en dit open die weg na die "oneindige gesprek" (Blanchot). Dit is die vertrekpunt van trans-individuering in 'n proses van kollektiewe individuering: praat en luister. Dit bring die ervaring van ware, egte transformasie na vore, wat eintlik individuering in die proses van Bildung (vorming) is, wat én ondergaan én bewerkstellig moet word. Die sleutel hiertoe is taal na die wese daarvan (Stiegler 2013:76). Die betekenis hiervan is dat die transformasie van menseverhoudinge juis in die wiele gery word deur die vernietiging van 'n taal eerder as om die transformasie van verhoudinge daardeur te bevorder. Die bevordering van tweedehandse eentaligheid ry juis hierdie noodsaaklike transformasie in die wiele.

\section{WIE EN WAT LY SKADE WANNEER TAAL IN HIERDIE DIEP SIN SKADE LY?}

Om saam te vat: Wanneer daar sprake is van die verwoesting, vernedering, instrumentalisering, marteling van taal wat is dit dan nou wat werklik skade ly? Wat is hierdie meer as, hierdie oorblyfsel, die restant, hierdie anders en meer as gereedskap, wat in die slag bly?

1 Vir Heidegger is dit ons synsverhouding: synsverlies, werklikheidsverlies, wêreldverlies, plek- en tuisteverlies.

2 Vir Ellul (1985:167) word taal verneder deur sin, die sinsverhouding, die restant te vernietig en te misken, wat die diepste wese van taal reflekteer. Dit skep 'n nihilisme, naamlik niks het meer sin of betekenis nie.

3 Volgens Ricoeur is dit wêreldverlies. Die instrumentalisering van taal vernietig die poëtiese vermoë van taal om wêrelde te open en te skep. Dit is presies waaraan ons vandag ly: die afwesigheid van 'n geskepte wêreld waarin almal sinvol kan lewe en bestaan, en meer nog: die afwesigheid van 'n gees van inventiwiteit wat nuwe, alternatiewe wêrelde kan of wil skep. Die gees van vandag sal eerder lei tot die vernietiging van wêrelde!

4 Vir Stiegler (2013:73) is dit same-lewingsverlies. Wanneer individuering en veral koindividuering, same-lewingstigting deur die misbruik en wangebruik van taal vernietig word dan word same-lewing voluit ontstig, gedisaffekteerde individue en samelewings geskep, maar dan ly die taal ook waarvan die wese eintlik same-lewingstigting in die diepste en mees intense sin denkbaar verteenwoordig en kan verwesenlik. 
Hierdie diepgaande verliese raak nie slegs diegene wie se taal dit is wat vernietig word nie, maar veral ook diegene wat hierdie verlies van taal inisieer, bevorder, bespoedig en verwesenlik. Hoekom het al diesulkes andersins verontskuldigings van allerlei aard?

\section{TERUG NA DIE OORSPRONGE}

Hoe kom ons terug by die "oorspronge" en die "wese", die ware synswyse van taal? Enkele opmerkings is reeds by die bespreking van sekere van die outeurs gemaak.

1 Heidegger wys op die erg problematiese hiervan, maar vra vir die kultivering van synsgevoeligheid, indringende denkmatigheid en luistersaamheid. Stop elke vorm van reduksie, byvoorbeeld deur drogredes, en doen dit deur behoorlike besinning en gesprekvoering. Die vererende aandagtigheid aan die onverborgenheid (waarheid) van wat ook al aanwesig is, die beskermende, sorgdraende kyk op die waarheid. Dit vra 'n ekstra sintuig. Taal maak dit moontlik.

2 Deur die oorgawe aan taal, wat oop is en bly vir die volle waarheid, as die kreatiewe en inventiewe skepper en bewerker van sinvolle bestaan met ander terwyl elke vorm van imbesiele reduksie van dit wat is geheel en al gestop moet word, soos byvoorbeeld: Taal is nie die sondaar nie en is ook nie 'n soort gereedskap nie. Die werkinge of handelinge van taal, en nie bloot die funksies (laag of hoog) nie, moet raakgesien word en ons moet ons daaraan oorgee en ons denke moet daaraan toevertrou word. Ons moet terugkom by die restant.

3 Verheerlik taal deur poëtisering, deur die herskepping van taal, deur die terugkeer na die permanente gees van taal, dit wil sê deur die oopstelling aan taal voor die werklikheid sodat nuwe wêrelde kan ontsluit en opduik, gesien kan word. Taal, waaraan so oorgegee word gee visie. Wêrelde, moontlikhede, word raakgesien wat andersins duister en onsigbaar sou bly. Die aandeel aan die doodmaak van 'n taal sal hom wreek deur die doding van alle tale sonder meer, die doding van die gehoor vir die Syn, die afstomping vir die invensie van sin en waarheid, en die verlies van alle moontlike wêrelde. Die grondloosheid van taal, waar taal sigself vier, is dit waarvan poësie die grootse en verhewe inspirasie vind en waardeur, met verbeelding (Valery), fantasma (Stiegler) en dromery (Bachelard) lood in goud verander word.

4 Deur taalvolheid as geestesvolheid na te jaag met besondere klem op hersimbolisering, woordeskatontwikkeling as werklikheidsbelewing en verwesenliking word nuwe samelewingsmoontlikhede geskep. Luister na die syn en skep woorde wat weergee wat ek hoor en vermy sodoende die marteling van taal wat belangrik is omdat die marteling sig kan wreek. Dit kan mense woordeloos laat, stomslaan, en dom maak - intellektuele infantilisme is diesulkes se voorland en ons land is oorbevolk met diesulkes - tweederangse en tweedehandse geletterdes en dit is letterlik lewensgevaarlik en die onvermoë tot ware same-lewing. "Vir'n nuwe situasie is 'n nuwe taal nodig", skrywe Serres (1995:72). Maak nuwe stories en verhale op! Dit is 'n uitdaging aan almal. Hiermee is ons terug by die gees van taal. Dit is dus 'n noëtiese oefening by uitstek.

Die vermoording en verwerping van 'n taal, die uitwerp van 'n taal op grond van drogredes, bring die "moordenaars" onvermydelik te staan voor die eie syns- of werklikheidsverlies, sinsverlies, waarheidsverlies, meelewendheidsverlies en uiteindelik wêreldverlies. Niemand kan armer, dooier en ellendiger wees as dit nie. Krokodiltrane mag uiteindelik ware trane word en moralistiese berouvolheid mag uiteindelik eerder op diep ervaarde gewetenswroeging uitloop. Die koste van die verwerping van 'n taal is nog nie werklik bereken nie - nóg vir die verworpenes, nóg vir die verwerpers. Die littekens wat universiteite aan hulleself gedoen het, en nog meer en meer voortgaan om te doen, sal onmiskenbaar teenwoordig bly. Kyk wat 
skrywe Michel Serres (1997:124) oor die lot van eentaligheid waaroor almal in vervoering is: "When all people of the world finally speak the same language and commune in the same message or the same norm of reason, we will descend, idiot imbeciles, lower than rats, more stupidly than lizards. The same maniacal language and science, the same repetitions of the same names in all latitudes - an earth covered with screeching parrots."

In die lig hiervan raak taalhandelinge dus besonder betekenisvol. Wanneer taal slegs "gereedskap" is, verloor dit hierdie dimensies en ook sy handelingskrag, want dit word dan slegs 'n bestuurbare, manipuleerbare entiteit, maar bestuurbaar deur feilbare, gebrekkige, dikwels oneerlike individue wat eiebelang of gesuggereerde of gewaande belang, of selfs ideologiese versinsels en sinistere verlangens, najaag.

\section{WATTER TAALHANDELINGE KRY ONS?}

Wanneer, en slegs wanneer, taal na sy ware aard en wese geag en gehuldig word en solank taal nie slegs as gereedskap geag word nie, sal die volgende wesenlike sake in menselewens verwesenlik word:

1 Taal bied 'n tuiste vir die Syn (huis, verblyfruimte, van die syn, van die werklikheid, van dit wat ook al is). Dit is wat mense tuismaak in die wêreld!! Die onsinnige geraas van die media, alle media, het so oorgeneem en ons oortuig dat dit al is wat waar is en belangrik, hulle besluit vir ons, dat ons nie meer kan luister na die Syn nie, dit nie kan hoor nie selfs nie verstaan wat die Syn beteken nie.

2 Taal is koesteraar van menslike geestelikheid waarsonder gees nie tot manifestasie kan kom nie. Die sekerste manier om gees te vergeet, is om taal volledig te laat opgaan in 'n stuk gereedskap vir berekening en rekenarisering en bestuurbaarheid en dus beheerbaarheid. Taal vereis 'n toegewyde verbintenis tot die wese van die menslike gees.

3 Taal is die inisieerder en verwesenliking van komposisionele denke en omvattende denke wat verbeeldingryk en fantasmaties en droomryk is en staan teenoor eendimensionele denke wat ons maklik en gewoonlik lei tot die graad nul van denke.

4 Taal is die skepper van wêrelde; dit is die poëtiese funksie daarvan (poësie is om te maak of te doen).

5 Taal is die skepper van etos, dus van plek, tuiste, in die volle betekenis daarvan.

6 Taal is die verwekker en bewusmaker van lewe, die bewaarder van lewe, die artikuleerder van lewe; die verfrisser en gewaarmaking daarvan.

7 Taal is behoeder en verwesenliker van same-lewing maar wat deur misbruik in al die vorme daarvan die verwoester van same-lewing is en ook van individue.

8 Taal is by uitstek die verwesenliker van lewensinvolheid in en deur al die bogenoemde handelinge en is in 'n sin die hoogtepunt van dit alles (waar meervoudige, konnektiewe intellek verwesenliking vind).

9 Taal is die inventeerder van ' $\mathrm{n}$ heilsame toekoms wat gesien moet word teenoor taal as gereedskap wat vernietiging deur katastrofe uitspel.

10 Om te eindig by die begin, by ons motto's: dit suggereer iets van die nimmereindigende, die onsterflike, die selfstandige oneindigheid van taal.

\section{SLOT}

Wanneer taal as gereedskap gebruik word en nie toegelaat word om self te doen en te gebruik en te skep nie is die skade onberekenbaar: die syn word verloor; sin gaan tot niet; wêrelde 
raak vermink; die toekoms raak weg; die gees verdor en raak vergete; denke verstar; lewe verval; gemeenskap is daarmee heen en die oneindige is ons nie beskore nie. Om taal slegs as gereedskap te sien, beteken om menswees af te sny van alle diepsinnige mensvormende taalhandelinge. Taal as gereedskap is vervangbaar en uitruilbaar. Die verlies van die restant van taal, aan die ander kant, is so erg soos lewensverlies.

Dit is goed dat daar gestry en geveg word vir die behoud van Afrikaanse instellinge. Wat die afgelope tyd met Afrikaanse instellinge gebeur, is krimineel en dit geld ook van diegene wat om watter rede ook al, ondanks krokodiltrane en gebare van berou, hieraan lustig en ook listig en selfs leedvermakerig meedoen. Dit vernietig alle moontlikhede wat Afrikaans vir alle Afrikaanssprekendes bied bo en behalwe om 'n stukkie gereedskap te wees. So 'n geveg het niks met regsheid te doen soos baie van diegene wat polities hiperkorrek wil wees, beweer nie. Hierdie stryd, om outentiek te wees, moet egter om veel meer gaan as bloot die behoud van instellinge wat Afrikaans as gereedskap gebruik, maar wat fokus op die herwinning van die Afrikaanse taal in die volheid daarvan as taalwees met die poëtiese krag van verbeelding, fantasma en dromery in die belang van ALLE Afrikaanssprekendes en vanselfsprekend ook in belang van almal met wie hulle saam lewe en in aanraking kom en die bewusmaking en kultivering hiervan binne sulke instellinge. Die wonder van taal, elke taal, wat 'n lofrede verdien, is slegs hierin geleë, en nie slegs in taal as blote gereedskap nie. Wanneer taal as blote gereedskap geag en verstaan word, maak dit al die gebruikers daarvan dom, sonder uitsig en hoop. Hier is dit miskien van pas om Derrida (2007) se woorde in herinnering te roep: 'n taal is nie iets wat behoort nie, dit wil sê dit is nie ons eiendom waarmee ons kan maak wat ons wil nie; dit is eerder iets waaraan ons behoort en waaraan ons ons moet oorgee sodat die poëtiese werkinge daarvan deur ons verwesenlik kan word.

\section{BIBLIOGRAFIE}

Arendt, H. 1982. Introduction: Walter Benjamin 1892-1940. In Benjamin, W. Illuminations. London: Fontana Books.

Atlan, H. 1986. Entre le cristal et la fumée. Paris: Seuil.

Bachelard, G. 1969. The poetics of reverie. Boston: Beacon Press.

Barthes, R. 1979. Writers, intellectuals, teachers. In Image-Music-Text. Glasgow: Fontana/Collins.

Benjamin, W. 1982. The task of the translator. In Illuminations. London: Fontana Books.

Derrida, J. 2007. Learning to live finally. Brooklyn, NY: Melville House.

Ellul, J. 1985. The humiliation of the word. Grand Rapids: Eerdmans.

Felman, S. 1982. Jacques Lacan and the adventure of insight. Cambridge (Mass.): Harvard University Press.

Girard, R. 2014. The one by whom scandal comes. East Lansing: Michigan State University Press.

Heidegger, M. 1955;1970. Wat is dat-filosofie? Tielt: Lannoo.

Heidegger, M.1947;1973. Brief over het humanisme. Tielt: Lannoo.

Latour, B. 1988. The Pasteurization of France. Cambridge: Harvard University Press.

Lecercle, J-J. 1985. Philosophy through the looking glass: Language, nonsense, desire. London: Hutchinson.

Lecercle, J-J. 1990. The violence of language. London: Routledge.

Ricoeur, P. 1976. Violence and language. In Political and social essays. Athens: Ohio University Press.

Ricoeur, P. 1991a. Poetry and possibility. In A Ricoeur Reader: Reflection and imagination, edited by Mario J. Valdes. Toronto: University of Toronto Press.

Ricoeur, P. 1991b. The creativity of language, in Valdes (1991).

Ricoeur, P. 1991c. Myth as bearer of possible wolds, in Valdes (1991).

Ricoeur, P. 2013a. Hermerneutics and the idea of revelation. In Hermeneutics: writings and lectures, vol. 2. Cambridge: Polity Press. 
Ricoeur, P. 2013b. Salvation myths and contemporary reason. In Hermeneutics (2013).

Serres, M. 1995. Conversations on Science, culture and time. Ann Arbor: The University of Michigan Press.

Serres, M. 1997. The troubadour of knowledge. Ann Arbor: The university of Michigan Press.

Serres, M. 2015. Bonheur aujourd'hui. Paris: Le Pommier.

Steiner, G. 1971. In Bluebeard's Castle: Some notes towards the re-definition of culture. London: Faber \& Faber.

Steiner, G. 2001. Grammars of creation. London: Faber \& Faber.

Steiner, G. 2005. Dix raisons (possibles) à la tristesse de pensée. Paris: Albin Michel.

Stiegler, B. 2013. Pharamacologie du Front national, suivi du Vocabulaire d'Ars industrialis. Paris: Flammarion.

Stiegler, B. \& Ars Industrialis. 2016. Reenchantment of the world: The value of spirit against industrial populism. London: Bloomsbury. 